Molecules 2008, 13, 995-1003

\title{
molecules
}

ISSN 1420-3049

(C) 2008 by MDPI

www.mdpi.org/molecules

Full Paper

\section{Novel Spiroannulated 3-Benzofuranones. Synthesis and Inhibition of the Human Peptidyl Prolyl cis/trans Isomerase Pin1}

\author{
Manfred Braun ${ }^{1, *}$, Anahita Hessamian-Alinejad ${ }^{1}$, Boris Féaux de Lacroix ${ }^{1}$, Birte Hernandez \\ Alvarez $^{2}$ and Gunter Fischer ${ }^{2}$ \\ ${ }^{1}$ Department of Chemistry, University of Düsseldorf, Universitätstr. 1, D-40225 Düsseldorf, Germany \\ 2 Max-Planck Research Unit for Enzymology of Protein Folding, Weinbergweg 22, D-06120 Halle, \\ Germany
}

* Author to whom correspondence should be addressed; E-mail: braunm@uni-duesseldorf.de

Received: 3 April 2008; in revised form: 22 April 2008 / Accepted: 23 April 2008 / Published: 29 April 2008

\begin{abstract}
The novel 3H-spiro[1-benzofuran-2-cyclopentan]-3-one skeleton has been made accessible by different routes. One- and two-step protocols lead to tricyclic and tetracyclic benzofuranones $\mathbf{2}$ and $\mathbf{3}$, respectively. A four-step synthesis to spirocompound $\mathbf{4}$ is described. The novel spirocyclic benzofuranones display modest to no inhibition of the human peptidyl prolyl cis/trans isomerase Pin1.
\end{abstract}

Keywords: Ketones; lithiation; cyclization; metathesis; spiroannulation

\section{Introduction}

Spirocyclic benzofuranones have attracted considerable attention with regard to their pharmaceutical activity and the various approaches directed towards their synthesis [1]. Aside from griseofulvin, known as an orally active antimycotic drug [2], synthetic and naturally occurring [3] compounds, which feature the spirobenzofuranone moiety, have been found to display inter alia antiinflammatory [4] and herbicidal activity [5] or act as aromatase inhibitors [6]. We have recently shown that synthetic spirocyclic 2-benzofuranones 1, involving a lactone skeleton, and aryl indanyl ketones 
are efficient inhibitors of the human peptidyl prolyl cis/trans isomerase Pin1 [7]. In this article, we describe the synthesis of 3-benzofuranones 2-4, the first representatives of the novel 3H-spiro-[1benzofuran-2-cyclopentan]-3-one skeleton and a screening of their inhibition of Pin1.

Scheme 1. Spirocyclic lactones 1 and novel spiroannulated 3-benzofuranones 2-4.

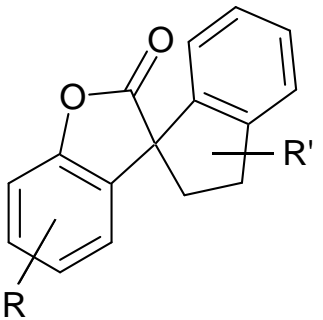

1<smiles>[R]c1ccc2c(c1)C(=O)C1(CC=CC1)O2</smiles>

2<smiles>[R]c1ccc2c(c1)C(=O)C1(Cc3ccccc3C1)O2</smiles>

3<smiles>COc1ccc2c(c1)C(=O)C1(CCc3ccccc31)O2</smiles>

4

\section{Results and Discussion}

Commercially available coumaranone $\mathbf{5 a}$ and the methoxy-substituted derivative $\mathbf{5 b}$ [8] served as the starting materials for the preparation of spirocyclic benzofuranones $\mathbf{2}$ and $\mathbf{3}$, as shown in Scheme 2.

Scheme 2. Synthesis of spiroannulated 3-benzofuranones 2 and 3.

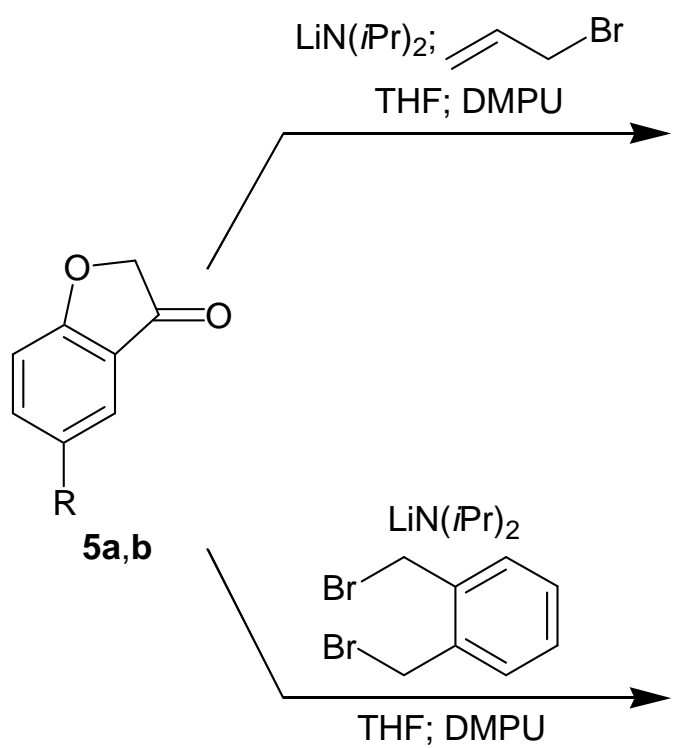

\begin{tabular}{ccc} 
2, 3, 5, 6: & a & b \\
\hline $\mathrm{R}=\mathrm{H}$ & $\mathrm{R}=\mathrm{OCH}_{3}$
\end{tabular}

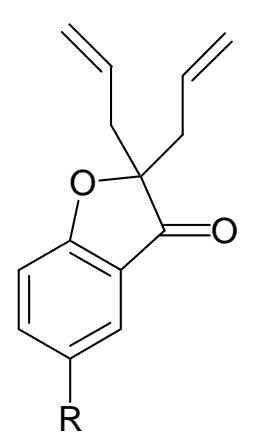<smiles>ClP(Cl)(Cl)(Cl)/C=C\c1ccccc1</smiles><smiles>CCCCCCCCCCCCCCCCC</smiles>

$$
\text { 6a (19\%) }
$$

6b $(36 \%)$<smiles>[R]c1ccc2c(c1)C(=O)C1(Cc3ccccc3C1)O2</smiles>

$3 \mathbf{a}(21 \%)$

3b $(26 \%)$<smiles>[R]c1ccc2c(c1)C(=O)C1(CC=CC1)O2</smiles>

2a (34\%)

2b (66\%) 
Thus, deprotonation of the ketones $\mathbf{5 a}$ a,b with lithium diisopropylamide and subsequent treatment with allyl bromide led to the dienes $\mathbf{6 a}, \mathbf{b}$. Although the protocol aimed at a double allylation, neither the base nor the electrophile were used in a 2:1 molar ratio with respect to the ketone because these conditions led mainly to the formation of aldol products and other side reactions that obviously consumed the electrophile. Although the allylic alkylation protocol was not thoroughly optimized, it was observed that the additive 1,3-dimethyltetrahydro-2(1H)pyrimidone (DMPU) was crucial, because, in its absence, the reaction failed completely. Ring closing metathesis [9] permitted conversion of the dienes $\mathbf{6 a}, \mathbf{b}$ into the spirocyclic ketones 2a,b. A one-step procedure led to the formation of spirocycles $\mathbf{3 a}, \mathbf{b}$ when the coumaranones $\mathbf{5 a , b}$ were treated with two equivalents of lithium diisopropylamide and $\alpha, \alpha^{\prime}$-dibromoxylene. Again, the yields were moderate due to various side reactions, wherein condensation and subsequent reduction-oxidation processes seem to take place prior to the desired reaction with the electrophile. Again, the protocol was not optimized.

Benzofuranone 4, isomeric to $\mathbf{3 b}$ and featuring an angular arrangement of the spirocyclic indane moiety was synthesized in a three-step protocol, outlined in Scheme 3. Thus, 2-bromo-1,4dimethoxybenzene (7a) was submitted to a bromine/lithium exchange to give lithioarene $\mathbf{7 b}$ and subsequently allowed to react with the lithium salt $\mathbf{8 b}$ generated from indanecarboxylic acid (8a). The ketone 9 thus obtained was selectively deprotected by treatment with aluminum chloride cleaving the methoxy group ortho to the carbonyl group.

Scheme 3. Synthesis of spiroannulated 3-benzofuranone 4.<smiles>[X]c1cc(OC)ccc1OC</smiles>

7a: $X=\mathrm{Br}$ 7b: $X=\mathrm{Li}$

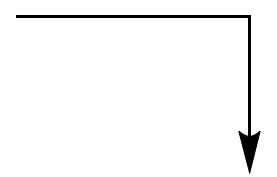<smiles>[X]C(=O)C1CCc2ccccc21</smiles><smiles>COc1ccc(OC)c(C(=O)C2CCc3ccccc32)c1</smiles>

8a: $X=O H$
8b: $X=O L i$

$9(55 \%)$<smiles>COc1ccc(O)c(C(=O)C2CCc3ccccc32)c1</smiles>

$\mathrm{BrCH}\left(\mathrm{CO}_{2} \mathrm{C}_{2} \mathrm{H}_{5}\right)_{2}$

$\mathrm{K}_{2} \mathrm{CO}_{3}$ $\mathrm{CH}_{3} \mathrm{COCH}_{2} \mathrm{CH}_{3}$<smiles>COc1ccc2c(c1)C(=O)C1(CCc3ccccc31)O2</smiles>

$4(36 \%)$ 
The conversion of ortho-hydroxy aryl ketones to 3-benzofuranones [10] was applied in the final step to the spiroannulated compound 4. Thus, phenolic ketone $\mathbf{1 0}$ was treated with ethyl bromomalonate in the presence of potassium carbonate and butanone, leading to 3-benzofuranone 4 in $36 \%$ yield. As a mechanistic explanation of this transformation, it is assumed that ethyl bromomalonate acts as an electrophilic brominating agent $[10,11]$ that brings about the introduction of the $\alpha$-bromo substituent into the ketone 10. Under the basic conditions, a final intramolecular nucleophilic substitution leads to a ring closure. It deserves to be mentioned that this protocol has neither been applied to the generation of quaternary carbon centers nor to the preparation of spirocyclic compounds. Although the yield is moderate and the product is accompanied by unidentified phenolic compounds, the latter can be easily separated by column chromatography. Thus, the protocol provides a ready access to the hitherto unknown spiroannulated system 4.

The inhibition of human Pin1 by the spiroannulated 3-benzofuranones 2-4 was determined in a protease-free PPlase assay with Suc-Ala-Glu-Pro-Phe-4-nitroanilide as substrate [12]. As shown in Table 1, the spirocompounds $\mathbf{2 b} \mathbf{b} \mathbf{3} \mathbf{b}$, and $\mathbf{4}$ (entries 2, 4, and 5) caused modest inhibition whereas two related compounds (2a and 3a) were completely inactive (entries 1 and 3). It seems that the 6-methoxy substituent in the benzofuranone fragment has a positive effect on the inhibition.

Table 1. Inhibition of benzofuranones 2-4.

\begin{tabular}{ccc}
\hline Entry & Benzofuranones & $\mathbf{K}_{\boldsymbol{i}}[\boldsymbol{\mu} \mathbf{M}]$ \\
\hline 1 & $\mathbf{2 a}$ & a) \\
2 & $\mathbf{2 b}$ & 65 \\
3 & $\mathbf{3 a}$ & a) \\
4 & $\mathbf{3 b}$ & 100 \\
5 & $\mathbf{4}$ & 77 \\
\hline
\end{tabular}

a) noninhibitory

\section{Conclusions}

Benzofuranones 2-4 featuring a novel spirocyclic skeleton have been synthesized in one- to threestep procedures. They were tested as inhibitors of a peptidyl prolyl cis/trans isomerase. This study shows, however, that the activity of the spiroannulated 3-benzofuranone derivatives 2-4 is distinctly lower than that obtained with the lactone-type spirocompounds $\mathbf{1}$ on the one hand [7a] and aryl indanyl ketones [7b, 13] on the other hand.

\section{Experimental}

\section{General}

Melting points (uncorrected) were determined with a Büchi melting points apparatus. IR spectra: Bruker Vector 22. Mass spectra: Varian MAT 311 A. NMR spectra: Bruker DRX 500 operating at 500 $\mathrm{MHz}\left({ }^{1} \mathrm{H}\right)$ and $125 \mathrm{MHz}\left({ }^{13} \mathrm{C}\right)$, respectively; all spectra were recorded in $\mathrm{CDCl}_{3}$. TLC: silica gel $60 \mathrm{~F}$ 254 (Merck). Column chromatography: Machery-Nagel Kieselgel 60 and Merck Kieselgel 60, mesh 
size 0.04-0.063. Elemental analyses were carried out with a Perkin Elmer CHN Analysator 263 at the Institute of Pharmaceutical Chemistry, University of Düsseldorf. 2-Coumaranone (5a), allyl bromide and 1,3-dimethyltetrahydro-2(1H)pyrimidone (DMPU) were purchased from Sigma-Aldrich Chemie $\mathrm{GmbH}$ and purified by distillation. Diisopropylamine (purity $>99.5 \%$ ) was also purchased from Sigma-Aldrich. $\alpha, \alpha$ '-Dibromo-o-xylene (purity $96 \%$ ) was obtained from the same supplier. It was refluxed over calcium hydride and distilled under nitrogen. General remarks concerning the handling of moisture and air-sensitive compounds are given in ref. [14].

General procedure for the double allylation of benzofuranones 5 (G. P. 1):

A 250-mL Schlenk-flask was equipped with a magnetic stirrer, a thermocouple and a septum and was connected to a combined argon/vacuum line. The air in the flask was replaced by argon. Diisopropylamine (1.49 g, $2.07 \mathrm{~mL}, 14.7 \mathrm{mmol}$ ) and dry THF (52 mL) were injected, and the mixture was stirred at $-78^{\circ} \mathrm{C}$. A solution of $n$-butyllithium $(9.75 \mathrm{~mL}, 15.6 \mathrm{mmol})$ in hexane was added at such a rate that the temperature did not exceed $-70^{\circ} \mathrm{C}$. Stirring was continued at $0^{\circ} \mathrm{C}$ for $30 \mathrm{~min}$.

In a $50 \mathrm{~mL}$ Schlenk-flask, benzofuranone 5 (12.3 mmol) was dissolved in dry THF (20 mL) under argon. This solution was added through a cannula to the mixture of lithium diisopropylamide, prepared as described above, at $-78^{\circ} \mathrm{C}$. Stirring was continued at the same temperature for $2 \mathrm{~h}$. Freshly distilled allyl bromide (1.73 g, $1.24 \mathrm{~mL}, 14.3 \mathrm{mmol}$ ) and 1,3-dimethyltetrahydro-2(1H)pyrimidone (DMPU) ( $1.89 \mathrm{~g}, 1.78 \mathrm{~mL}, 14.7 \mathrm{mmol}$ ) were injected. The mixture was allowed to warm up to room temperature overnight and stirred for $48 \mathrm{~h}$ at this temperature. The solution was washed with a saturated aqueous solution ( $50 \mathrm{~mL}$ ) of $\mathrm{NH}_{4} \mathrm{Cl}$. The aqueous solution was extracted with chloroform (3 times $50 \mathrm{~mL}$ ). The organic layers were combined and dried with $\mathrm{Na}_{2} \mathrm{SO}_{4}$. The solvent was removed in a rotary evaporator and the oily residue was purified by column chromatography on silica gel. According to this procedure the following products were obtained:

2,2-Bis(prop-2-en-1-yl)-2,3-dihydro-1-benzofuran-3-one (6a): Prepared from 5a; $R_{\mathrm{f}}=0.57$ (nhexane/ethyl acetate, 10 : 1); yield (relative to 5a): $19 \%$; ${ }^{1} \mathrm{H}-\mathrm{NMR}: \delta 2.53-2.63\left(\mathrm{~m}, 4 \mathrm{H}, \mathrm{CH}_{2} \mathrm{CH}=\mathrm{CH}_{2}\right.$ ), 5.02 (dd, $J=10.1 \mathrm{~Hz}, J=1.6 \mathrm{~Hz}, 2 \mathrm{H}, \mathrm{CH}_{2} \mathrm{CH}=\mathrm{CHH}$ ), 5.13 (dd, $J=17.3 \mathrm{~Hz}, J=1.6 \mathrm{~Hz}, 2 \mathrm{H}$, $\mathrm{CH}_{2} \mathrm{CH}=\mathrm{CHH}$ ), 5.59-5.67 (m, 2H, $\mathrm{CH}_{2} \mathrm{CH}=\mathrm{CH}_{2}$ ), 7.03-7.26 (m, 2H, aromatic H), 7.58-7.60 (m, 2H, aromatic H); ${ }^{13} \mathrm{C}-\mathrm{NMR}: \delta$ 39.9, 91.3, 113.2, 119.8, 121.4, 121.7, 124.2, 130.5, 138.1, 171.8, 203.2; IR (thin film, $\mathrm{cm}^{-1}$ ): 3050, 2955, 1710, 1490, 1435, 1340, 1275, 1245, 1215, 1140, 1030, 825, 755; MS (70 eV): m/z (\%): 214 (28, [M] ${ }^{+}$), 199 (6), 185 (6), 172 (100), 147 (12), 145 (40), 128 (56), 115 (32), 91, (28), 76 (27), 65 (36), 55 (42); HRMS: (EI) calcd. for $\mathrm{C}_{14} \mathrm{H}_{14} \mathrm{O}_{2}$ : 214.0994, found 214.0993.

5-Methoxy-2,2-bis(prop-2-en-1-yl)-2,3l-dihydro-1-benzofuran-3-one (6b): Prepared from 5b; $R_{\mathrm{f}}=0.57$ (ethyl acetate); yield (relative to 5b): 36\%; ${ }^{1} \mathrm{H}-\mathrm{NMR}: \delta 2.52-2.61\left(\mathrm{~m}, 4 \mathrm{H}, \mathrm{CH}_{2} \mathrm{CH}=\mathrm{CH}_{2}\right.$ ), 3.79 (s, 3H, $\mathrm{OCH}_{3}$ ), 5.02 (dd, $J=8.5 \mathrm{~Hz}, J=1.0 \mathrm{~Hz}, 2 \mathrm{H}, \mathrm{CH}_{2} \mathrm{CH}=\mathrm{CHH}$ ), 5.12 (dd, $J=17.0 \mathrm{~Hz}, \mathrm{~J}=1.0 \mathrm{~Hz}, 2 \mathrm{H}$, $\mathrm{CH}_{2} \mathrm{CH}=\mathrm{CHH}$ ), 5.58-5.63 (m, 2H, $\mathrm{CH}_{2} \mathrm{CH}=\mathrm{CH}_{2}$ ), 7.00-7.10 (m, 2H, 4H, and 7-H), 7.24 (dd, $J=9.1$ $\mathrm{Hz}, J=2.8 \mathrm{~Hz}, 1 \mathrm{H}, 6-\mathrm{H}) ;{ }^{13} \mathrm{C}-\mathrm{NMR}: \delta 40.0,55.8,92.0,103.8,114.1,119.7,121.2,128.3,130.6$, 154.8, 167.2, 203.5; IR (thin film, $\mathrm{cm}^{-1}$ ): 3060, 2910, 1710, 1490, 1435, 1340, 1275, 1245, 1215, 1140, 
1030, 825, 775; MS (70 eV): m/z (\%): 244 (100, [M] $\left.]^{+}\right), 217$ (13), 203 (88), 175 (21), 150 (32), 124 (12), 123 (19), 91 (15), 79 (18), 55 (27).

General procedure for the preparation of spiroannulated benzofuranones 2 by ring-closing metathesis (G. P. 2):

A mixture of benzylidene-bis-(tricyclohexylphosphino)-dichlororuthenium ("Grubbs catalyst I") (0.016 g, $0.02 \mathrm{mmol})$ in dry dichloromethane $(50 \mathrm{~mL})$ was stirred under argon in a 100-mL flask equipped with a magnetic stirrer, a septum and a connection to the combined argon/vacuum line. At room temperature, diallyl compound 6 (4.0 mmol), dissolved in $6 \mathrm{~mL}$ of dry dichloromethane, was added and the mixture was stirred at room temperature for $19 \mathrm{~h}$. The solvent was removed in a rotary evaporator and the residue was purified by column chromatography. According to this procedure the following products were obtained:

3H-Spiro[1-benzofuran-2,1'-cyclopentan]-3'-en-3-one (2a): Prepared from 6a; colorless oil; $R_{\mathrm{f}}=0.43$ (chloroform); yield: 34\%; ${ }^{1} \mathrm{H}-\mathrm{NMR}$ : $\delta 2.69$ (d, $J=17.0 \mathrm{~Hz}, 2 \mathrm{H}, 2^{\prime}-\mathrm{H}$ and 5'-H), 2.95 (d, $J=17.0 \mathrm{~Hz}$, 2H, 2'-H and 5'-H), 5.81 (s, 2H, 3'-H and 4'-H), 7.07-7.10 (m, 2H, aromatic H), 7.60-7.64 (m, 2H, aromatic H); ${ }^{13} \mathrm{C}-\mathrm{NMR}: \delta 44.1,95.4,113.4,120.6,212.8,124.5,127.8,138.1,171.4,203.8$; IR (thin film, $\mathrm{cm}^{-1}$ ): 3060, 2920, 2850, 1710, 1615, 1460, 1325, 1270, 1205, 1135, 1035, 945, 920, 845, 760, 680; MS (70 eV): m/z (\%): $186\left(100,\left[\mathrm{M}^{+}\right), 171\right.$ (46), 157 (12), 121 (96), 92 (36). Anal. calcd. for $\mathrm{C}_{12} \mathrm{O}_{2} \mathrm{H}_{10}$ : C, 77.40; H, 5.41. Found C, 77.71; H, 5.41.

5-Methoxy-3H-spiro[1-benzofuran-2,1'-cyclopentan]-3'-en-3-one (2b): Prepared from 6b; colorless oil; $R_{\mathrm{f}}=0.71$ (chloroform); yield: 66\%; ${ }^{1} \mathrm{H}-\mathrm{NMR}: \delta 2.68$ (d, $J=16.8 \mathrm{~Hz}, 2 \mathrm{H}, 2^{\prime}-\mathrm{H}$ and 5'-H), 2.94 (d, $J=16.8 \mathrm{~Hz}, 2 \mathrm{H}, 2^{\prime}-\mathrm{H}^{\prime}$ and 5'-H), 3.80 (s, 3H, $\mathrm{OCH}_{3}$ ), 5.80 (s, 2H, 3'-H and 4'-H), 7.10 (d, $J=9.1 \mathrm{~Hz}$, $1 \mathrm{H}, 7-\mathrm{H}), 7.08$ (d, $J=2.8 \mathrm{~Hz}, 1 \mathrm{H}, 4-\mathrm{H}), 7.26$ (dd, $J=9.1 \mathrm{~Hz}, J=2.8 \mathrm{~Hz}, 1 \mathrm{H}, 6-\mathrm{H}) ;{ }^{13} \mathrm{C}-\mathrm{NMR}: \delta 44.1$, 55.9, 96.1, 104.1, 114.3, 120.3, 127.8, 128.2, 195.0, 166.9, 204.0; IR (thin film, $\mathrm{cm}^{-1}$ ): 3070, 2940, 2835, 1705, 1600, 1490, 1440, 1275, 1235, 1205, 1130, 1030, 875, 825, 755; MS (70 eV): m/z (\%): $216\left(61,[\mathrm{M}]^{+}\right), 204$ (10), 151 (100), 150 (57).

General procedure for the preparation of spiroannulated benzofuranones 3 (G. P. 3):

According to G. P. 1, benzofuranones 5 were deprotonated with lithium diisopropylamide. Then, the solution was treated with 1 equivalent (relative to 5) of $\alpha, \alpha^{\prime}$-dibromo-o-xylene, dissolved in THF, and 1 equivalent of DMPU. The mixture was warmed up to room temperature. After work up according to G. P. 1, the residue was purified by column chromatography. According to this procedure the following compounds were obtained:

1',3'-Dihydro-3H-spiro[benzofuran-2,2'-indene]-3-one (3a): Prepared from 5a; colorless oil; $R_{\mathrm{f}}=$ 0.43 (n-hexane/ethyl acetate, 10:1); yield: 21\%; ${ }^{1} \mathrm{H}-\mathrm{NMR}$ : $\delta 3.18$ (d, $J=17.0 \mathrm{~Hz}, 2 \mathrm{H}, 1{ }^{\prime}-\mathrm{H}$ and 3'-H), 3.55 (d, $J=17.0 \mathrm{~Hz}, 2 \mathrm{H}, 1^{\prime}-\mathrm{H}$ and 3'-H), 7.05-7.73 (m, 8H, aromatic H); ${ }^{13} \mathrm{C}-\mathrm{NMR}: \delta 44.0,97.2$, 114.0, 121.0, 122.2, 125.0, 127.8, 138.7, 140.0, 171.8, 202.7; IR (thin film, $\mathrm{cm}^{-1}$ ): 2940, 1710, 1615, 
1460, 1330, 1285, 1195, 1020, 915, 685; MS (70 eV): m/z (\%): 236 (88, [M] ), 219 (11), 121 (100), 115 (41). Anal. calcd. for $\mathrm{C}_{17} \mathrm{H}_{12} \mathrm{O}_{2}$ : C, 81.34; H, 5.12. Found C, 81.04; H, 5.15.

5-Methoxy-1',3'dihydro-3H-spiro[1-benzofuran-2,2'-indene]-3-one (3b): Prepared from 5b; colorless oil; $R_{\mathrm{f}}=0.73$ ( $n$-hexane/ethyl acetate, 2:1); yield: 26\%; ${ }^{1} \mathrm{H}-\mathrm{NMR}: \delta 3.18$ (d, $J=16.7 \mathrm{~Hz}, 2 \mathrm{H}, 1^{\prime}-\mathrm{H}$ and 3'-H), 3.55 (d, $J=16.7 \mathrm{~Hz}, 2 \mathrm{H}, 1^{\prime}-\mathrm{H}$ and 3'-H), 3.82 (s, 3H, $\mathrm{OCH}_{3}$ ), 7.00 (d, $J=9.1 \mathrm{~Hz}, 1 \mathrm{H}, 7-\mathrm{H}$ ), 7.11 (d, $J=2.8 \mathrm{~Hz}, 1 \mathrm{H}, 4-\mathrm{H}), 7.24-7.28$ (m, 5H, remaining aromatic $\mathrm{H}$ ); ${ }^{13} \mathrm{C}-\mathrm{NMR}: \delta 43.7,56.0,97.5$, 104.2, 114.5, 120.5, 124.6, 127.3, 128.4, 139.7, 155.0, 166.8, 202.5; IR (thin film, $\mathrm{cm}^{-1}$ ): 2940, 1700, 1490, 1350, 1280, 1230, 1195, 1125, 1025, 840, 740; MS (70 eV): m/z (\%): 266 (19, [M] $\left.{ }^{+}\right), 207$ (22), 205 (96), 183 (59), 140 (54), 105 (100), 103 (31), 78 (37), 58 (31).

\section{(2,3-Dihydro-1H-inden-1-yl) (2,5-dimethoxyphenyl)methanone (9):}

Under nitrogen, a solution of 7a $(6.015 \mathrm{~g}, 27.27 \mathrm{mmol})$ in dry diethyl ether $(60 \mathrm{~mL})$ was stirred at $-78^{\circ} \mathrm{C}$ in a two-necked flask, equipped with a magnetic stirrer, a septum and a connection to the nitrogen/vacuum line. A solution of $n$-butyllithium $(19.8 \mathrm{~mL}, 31.6 \mathrm{mmol})$ was added slowly by syringe, and stirring was continued at the same temperature for $30 \mathrm{~min}$. In a second flask, 1indanecarboxylic acid (8a, 2.25 g, $14.0 \mathrm{mmol}$ ) was dissolved in dry diethyl ether (30 mL), and treated at $-78^{\circ} \mathrm{C}$ under stirring with a solution of $n$-butyllithium $(8.6 \mathrm{~mL}, 13.8 \mathrm{mmol})$. Stirring was continued at $20^{\circ} \mathrm{C}$ for $30 \mathrm{~min}$. The solution of the first flask was added through a cannula, and the mixture was allowed to reach room temperature overnight. Water $(20 \mathrm{~mL})$ was added, followed by $2 \mathrm{~N}$ hydrochloric acid $(3 \mathrm{~mL})$ and the aqueous layer was extracted three times with diethyl ether. The combined organic layers were dried with magnesium sulfate, the solvent was removed in a rotary evaporator and the residue was purified by column chromatography to give colorless, oily 9 (1,68 g, 55\%); $R_{\mathrm{f}}=0.36$ (chloroform); ${ }^{1} \mathrm{H}-\mathrm{NMR}: \delta$ 2.32-2.52 (m, 2H, $\mathrm{CH}_{2}$ ), 2.88-2.99 (m, 2H, $\mathrm{CH}_{2}$ ), 3.76 (s, $3 \mathrm{H}, \mathrm{OCH}_{3}$ ), 3.87 (s, 3H, $\mathrm{OCH}_{3}$ ), 5.12 (dd, $J=8.5 \mathrm{~Hz}, J=5.8 \mathrm{~Hz}, 1 \mathrm{H}, \mathrm{COCH}$ ), 6.95 (d, $J=8.9 \mathrm{~Hz}, 1 \mathrm{H}$, 3-H), 7.04 (dd, $J=8.9 \mathrm{~Hz}, J=3.2 \mathrm{~Hz}, 1 \mathrm{H}, 4-\mathrm{H}), 7.09$ (d, $J=3.2 \mathrm{~Hz}, 1 \mathrm{H}, 6-\mathrm{H}), 7.05-7.26$ (m, 4H, indenyl aromatic $\mathrm{H}$ ); ${ }^{13} \mathrm{C}-\mathrm{NMR}$ : $\delta$ 29.5, 32.5, 56.9, 57.2, 58.6, 113.6, 115.1, 119.7, 125.1, 125.6, 126.6, 127.6, 129.6, 142.6, 145.1, 153.0, 154.0, 203.9; IR (thin film, $\mathrm{cm}^{-1}$ ): 2940, 1675, 1495, 1465, 1410, 1280, 1225, 815, 755; MS (70 eV): m/z (\%): 282 (4, [M] ), 165 (100), 150 (6), 122 (7), 115 (10), 92 (6), 77 (10).

\section{2-(2,3-Dihydro-1H-inden-1-ylcarbonyl)-4-methoxyphenol (10):}

In a 250-mL flask equipped with a drying tube, 9 (1.68 g, $7.64 \mathrm{mmol})$ was dissolved in dichloromethane and cooled to $0^{\circ} \mathrm{C}$. Aluminum chloride $(5 \mathrm{~g}, 37.5 \mathrm{mmol})$ were added, and stirring was continued at $0^{\circ} \mathrm{C}$ for $1 \mathrm{~h}$ and at room temperature for another $70 \mathrm{~min}$. Water $(20 \mathrm{~mL})$ and $2 \mathrm{~N}$ hydrochloric acid $(20 \mathrm{~mL})$ were added carefully. The organic layer was separated and the aqueous phase was extracted three times with chloroform. The combined organic layers were dried with magnesium sulfate, the solvent was removed under reduced pressure, and the residue was purified by column chromatography to give crystalline, yellow 10 (1.06, 52\%); $R_{\mathrm{f}}=0.59$ (chloroform); mp. 105$106^{\circ} \mathrm{C} ;{ }^{1} \mathrm{H}-\mathrm{NMR}: \delta 2.41-2.56\left(\mathrm{~m}, 2 \mathrm{H} \mathrm{CH}_{2}\right), 2.98-3.24\left(\mathrm{~m}, 2 \mathrm{H}, \mathrm{CH}_{2}\right), 3.82\left(\mathrm{~s}, 3 \mathrm{H}, \mathrm{OCH}_{3}\right), 5.03(\mathrm{t}, J=$ 
$7.7 \mathrm{~Hz}, 1 \mathrm{H}, \mathrm{COCH}), 6.98$ (d, $J=9.1 \mathrm{~Hz}, 1 \mathrm{H}, 6-\mathrm{H}), 7.17$ (dd, $J=9.1 \mathrm{~Hz}, J=3.0 \mathrm{~Hz}, 1 \mathrm{H}, 5-\mathrm{H}), 7.39$ (d, $J=3.0 \mathrm{~Hz}, 1 \mathrm{H}, 3-\mathrm{H}), 7.10-7.33$ (m, 4H, indenyl aromatic $\mathrm{H}$ ), 12.0 (s, $1 \mathrm{H}, \mathrm{OH}) ;{ }^{13} \mathrm{C}-\mathrm{NMR}: \delta 30.0$, 32.0, 52.2, 56.0, 113.4, 118.6, 119.6, 124.3, 124.9, 125.0, 126.5, 127.7, 141,0, 144.7, 151.8, 157.8, 206.3; IR (thin film, $\mathrm{cm}^{-1}$ ): 3060, 3006, 2939, 2846, 1644, 1615, 1481, 1418, 1353, 1242, 1212, 1165, 1039, 829, 788, 753; MS (70 eV): m/z (\%): 268 (21, [M] $\left.]^{+}\right), 151$ (100), 117 (12), 115 (13), 95 (5). Anal. calcd. for $\mathrm{C}_{17} \mathrm{H}_{16} \mathrm{O}_{3}$ : C, 76.10; H, 6.01. Found C, 75.82; H, 5.98.

5-Methoxy-2',3'-dihydro-3H-spiro[1-benzofuran-2,1'-indene]-3-one (4):

Under nitrogen, a mixture of 10 (57.6 $\mathrm{mg}, 0.215 \mathrm{mmol}$ ), diethyl bromomalonate (77 $\mathrm{mg}, 0.322$ $\mathrm{mmol}$ ), anhydrous potassium carbonate ( $89 \mathrm{mg}, 0.645 \mathrm{mmol}$ ) and dry butanone were refluxed for $9 \mathrm{~h}$. The mixture was filtered and the residue was washed with butanone. The combined filtrates were evacuated and the residue was submitted to a column chromatography. The yellowish crude product was recrystallized from ethanol to give 4 in $36 \%$ yield $\left(20.5 \mathrm{mg}\right.$ ); $R_{\mathrm{f}}=0.41$ (chloroform); $\mathrm{mp} 129^{\circ} \mathrm{C}$; ${ }^{1} \mathrm{H}-\mathrm{NMR}: \delta 2.45$ (ddd, $J=13.8 \mathrm{~Hz}, J=4.7 \mathrm{~Hz}, J=8.5 \mathrm{~Hz}, 1 \mathrm{H}, \mathrm{CHH}$ ), 2.67 (ddd, $1 \mathrm{H}, J=13.8 \mathrm{~Hz}, J=$ $6.5 \mathrm{~Hz}, J=8.5 \mathrm{~Hz}, 1 \mathrm{H}, \mathrm{CHH}), 3.15-3.33\left(\mathrm{~m}, 2 \mathrm{H}, \mathrm{CH}_{2}\right), 3.83$ (s, 3H, $\left.\mathrm{OCH}_{3}\right), 6.89$ (d, $\left.J=7.7 \mathrm{~Hz}, 1 \mathrm{H}\right)$, $6.96(\mathrm{~d}, 1 \mathrm{H}, J=9.0 \mathrm{~Hz}$ ), 7.04 (d, $J=2.8 \mathrm{~Hz}, 1 \mathrm{H}), 7.09$ (pseudo-t, $J=6.8 \mathrm{~Hz}, 1 \mathrm{H}), 7.20$ (m, 1H), and 7.27 (m, 1H) (aromatic H); ${ }^{13} \mathrm{C}-\mathrm{NMR}: \delta$ 30.6, 35.9, 55.9, 98.9, 104.3, 114.3, 120.2, 123.2, 125.2, 127.2, 128.3, 129.8, 140.1, 145.6, 155.0, 167.4, 202.8; IR (thin film, $\mathrm{cm}^{-1}$ ): 3070, 2921, 2851, 1708, 1604, 1551, 1481, 1430, 1341, 1263, 1206, 1158, 1095, 1026, 998, 938, 915, 836, 801, 755, 652; MS (70 eV): m/z (\%): 266 (56, [M] $\left.]^{+}\right), 151$ (100), 123 (11), 115 (24), 32 (68); HRMS: (EI) cald. for $\mathrm{C}_{17} \mathrm{H}_{14} \mathrm{O}_{3}$ : 266.0943, found 266.0940 .

\section{Acknowledgements}

This work was supported by the Deutsche Forschungsgemeinschaft. High resolution mass spectra were kindly measured by Priv.-Doz. Dr. Wolfgang Schrader, Max-Planck-Institut für Kohlenforschung, Mülheim/Ruhr. We are grateful to Sabine Houben, Stefan Lachenicht, and Sebastian Schlecht for their assistance with the preparation of several compounds.

\section{References and Notes}

1. (a) Röhrkasten, R.; Konrad, M. In Houben Weyl, Methoden der Organischen Chemie, $4^{\text {th }}$ edition, Thieme: Stuttgart, 1994; Vol. E6b1, Part 2a, pp. 33-162; (b) Dell, C. P. In Science of Synthesis, Thieme: Stuttgart, 2000; Vol. 10.1, p. 11.

2. (a) The Merck Index; $11^{\text {th }}$ edition; Budavari, S., Ed.; Merck and Co Inc.; Rahway, NJ, 1989; p. 715; (b) The Merck Index; 14 $4^{\text {th }}$ edition; Merck and Co., Inc.: Whitehouse Station, NJ, 2006; www.merckindex.com "griseofulvin".

3. (a) Sonntag, B.; Dasenbrock, J.; Arnold, N.; Steglich, W. Metabolites from the wood-rotting basidomycete Hapalopilus mutans. Eur. J. Org. Chem. 1999, 1051-1055; (b) Edwards, J. M.; Mangion, M.; Anderson, J. P.; Rapposch, M.; Hite, G. Pigments of Lachnanthes tinctoria Ell. Part 
IX. Lachnanthospirone, a dimeric 9-phenylphenalenone from the seeds of Lachnanthes tinctoria Ell. Tetrahedron Lett. 1979, 4453-4456.

4. Yang, L.; Qin, L.-H.; Bligh, S. W. A.; Bashall, A.; Zhang, C.-F.; Zhang, M.; Wang, Z.-T.; Xu, L.S. A new phenanthrene with a spirolactone from Dendrobium chrysantum and its antiinflammatory activities. Bioorg. Med. Chem. 2006, 14, 3496-3501.

5. Gates, P. S.; Baldwin, D.; Wilson, C. A.; Gillon, J. Herbicidal 5-cyano-2,3-dihydrobenzofuran-2ones. U.S. 4263037, 1982; [Chem. Abstr. 1982, 97, 215978].

6. Edwards, P. N.; Large, M. S. Preparation of 8-(triazolylmethyl)naphtho[2,1-b]furanones and analogs as aromatase inhibitors. EP 316079, 1989; [Chem. Abstr. 1989, 111, 232794].

7. (a) Hernandez Alvarez, B.; Fischer, G.; Braun, M.; Hessamian-Alinejad, A.; Fliri, H. Preparation of spiro ketone and carboxylic acid derivatives as specific inhibitors for $\left(\mathrm{PO}_{3} \mathrm{H}_{2}\right) \mathrm{Ser} /\left(\mathrm{PO}_{3} \mathrm{H}_{2}\right) \mathrm{Thr}-$ Pro-specific peptidyl-prolyl-cis/trans isomerases. WO 2003093258, 2003; [Chem. Abstr. 2003, 139, 381371]; (b) Daum, S.; Erdmann, F.; Fischer, G.; Féaux de Lacroix, B.; Hessamian-Alinejad, A.; Houben, S.; Frank, W;. Braun, M. Aryl Indanyl Ketones: Efficient Inhibitors of the Human Peptidyl-Prolyl cis/trans Isomerase Pin1. Angew. Chem. Int. Ed. 2006, 45, 7454-7458.

8. Hammond, M. L.; Zambias, R. A.; Chang, M. N.; Jensen, N. P.; McDonald, J.; Thompson, K.; Boulton, D. A.; Kopka, I. E.; Hand, K. M.; Opas, E. E.; Luell, S.; Bach, T.; Davies, P.; MacIntyre, D. E.; Bonney, R. J.; Humes, J. L. Antioxidant-based inhibitors of leukotriene biosynthesis. The discovery of 6-[1-[2-(hydroxymethyl)phenyl]-1-propen-3-yl]-2,3-dihydro-5-benzofuranol, a potent topical antiinflammatory agent. J. Med. Chem. 1990, 33, 908-918.

9. Schmidt, B. Ruthenium-catalyzed cyclizations: more than just olefin metathesis. Angew. Chem. Int. Ed. 2003, 42, 4996-4999.

10. Kanvinde, M. N.; Kelkar, R. M.; Paradkar, M. V. Unusual Behaviour of Diethylbromomalonate with 2-Hydroxydesoxybenzoins. Convenient Synthesis of 2-Aryl-3(2H)-benzofuranones. Synth. Commun. 1993, 23, 961-969.

11. Cf. Coumbarides, G. S.; Dingjan, M.; Eames, J.; Weerasooriya, N. Investigations into the Bromination of Substituted Phenols using Diethyl Bromomalonate and Diethyl Dibromomalonate. Bull. Chem. Soc. Jpn. 2001, 74, 179-180;

12. Janowski, B.; Wöllner, S.; Schutkowski, M.; Fischer, G. A protease-free assay for peptidyl prolyl cis/trans isomerases using standard peptide substrates. Anal. Biochem. 1997, 252, 299-307.

13. This is illustrated by the result that the $K_{i}$ value of ketone $\mathbf{1 0}$ amounts to $8.7 \mu \mathrm{M}$, determined with the same PPIase assay: Daum, S.; Fischer, G.; Féaux de Lacroix, B.; Hessamian-Alinejad, A.; Braun, M. unpublished data.

14. Devant, R.; Mahler, U.; Braun, M. Stereoselektive Aldolreaktionen mit (R)- und (S)-(2-Hydroxy1,2,2-triphenylethyl)acetat und verwandten Glycolmonoacetaten. Chem. Ber. 1988, 121, 397-406.

Sample Availability: Samples of the compounds 6a, 9, 10, 4 are available from authors.

(C) 2008 by MDPI (http://www.mdpi.org). Reproduction is permitted for noncommercial purposes. 